\title{
Možnosti zvýšení adherence k léčbě u pacientů s kardiovaskulárním rizikem
}

Praktickým tématem zlepšení adherence pacientů se zvýšeným kardiovaskulárním (KV) rizikem $\mathrm{k}$ léčbě se zabývalo samostatné symposium, které proběhlo v rámci XXI. kongresu České internistické společnosti v říjnu 2014 v Brně. Pod předsednictvím prof. MUDr. Miroslava Součka, CSc. (II. interní klinika, LF MU a FN u sv. Anny, Brno) rozebírali tuto problematiku z hlediska prínosu fixních kombinací v léčbě hypertenze a dyslipidemie prof. MUDr. Hana Rosolová, DrSc. (Centrum preventivní kardiologie, II. interní klinika, LF Plzeň UK v Praze a FN Plzeň) a doc. MUDr. Michal Vrablík, Ph.D. (III. interní klinika, 1. LF UK a VFN, Praha).

\section{Fixní kombinace může zvýšit adherenci $\mathbf{k}$ antihypertenzní léčbě}

Jak připomněla prof. Rosolová, compliance k léčbě zahrnuje adherenci (pravidelné a správné užívání všech dávek) a perzistenci (užívání léku v čase). Je velkým problémem chronické medikace, zejména v primární prevenci u chronických asymptomatických chorob, jako je hypertenze a dyslipidemie. Mladší muži s hypertenzí užívají po dvou letech od zahájení terapie antihypertenziva pouze ve 40 \%, ale adherence rychle klesá ve všech věkových skupinách. Nejlepší perzistence k antihypertenzní léčbě byla zjištěna u blokátorů systému renin-angiotensin-aldosteron (RAAS).

Bylo prokázáno, že při zahájení léčby hypertenze dvojkombinací léků je dosaženo pětinásobně vyšší účinnosti než při monoterapii se zvyšováním dávky. Je to dáno ovlivněním více mechanismů vzniku hypertenze. Fixní kombinace léků zvýší adherenci k léčbě průměrně o $20 \%$. Mezinárodní i česká doporučení uvádějí jako nejvhodnější kombinaci antihypertenziv inhibitory enzymu konvertujícího angiotensin (ACEI) s blokátory kalciových kanálů (BKK), zejména z důvodu vzájemně se doplňujícího účinku těchto léků na strukturu a funkci arterií.

Prof. Rosolová se zaměřila na fixní kombinaci $B K K$ verapamilu a ACEI trandolaprilu. Do studie INVEST byli zařazeni hypertonici s ischemickou chorobou srdeční (ICHS). Studie porovnávala atenolol později v kombinaci s hydrochlorothiazidem (HCTZ) a trandolaprilem oproti verapamilu s trandolaprilem a možným přidáním HCTZ. Obě kombinace vedly k podobnému snížení výskytu KV příhod, nefatálního infarktu myokardu, cévních mozkových příhod (CMP) i celkové mortality. Studie došla k závěru, že trandolapril + verapamil je vhodnou kombinací $i$ u pacientů se stabilní ICHS bez srdečního selhání. Do randomizované kontrolované studie STAR byli zařazeni pacienti s metabolickým syndromem a porušenou glukózovou tolerancí. V hlavní zaslepené části byla porovnávána fixní kombinace trandolapril + verapamil s kombinací losartan + HCTZ. Účinek na snížení systolického tlaku krve (STK) i diastolického tlaku krve (DTK) byl po jednom roce léčby $v$ obou skupinách srovnatelný, ovšem primární sledovaný parametr - glykemie ve druhé hodině orálního glukózového tolerančního testu (oGTT) - byl ve skupině s trandolaprilem + verapamilem snížen, zatímco ve druhé skupině došlo k jeho zvýšení (statisticky významný rozdíl).
U kombinace trandolapril + verapamil navíc došlo v průběhu studie ke snížení koncentrace inzulinu a k nižšímu výskytu diabetu 2. typu.

\section{Shrnutí}

Adherence hypertoniků $\mathrm{k}$ léčbě je velmi nízká, přičemž horší je v nižších věkových skupinách a u mužů. Adherenci prokazatelně zvyšují fixní kombinace lékư doporučené již v iniciální léčbě v prípadě vysokých hodnot TK nebo nižších cílových hodnot TK. Kombinace ACEI trandolaprilu s BKK verapamilem je velmi účinná při snižování TK a má kardioprotektivní, nefroprotektivní a příznivé metabolické účinky.

\section{Nová fixní kombinace může zvýšit adherenci k léčbě dyslipidemie}

Problémem adherence pacientů $\mathrm{k}$ léčbě dyslipidemie se zabýval doc. Vrablík. Zaměřil se především na diabetiky s KV onemocněním, u nichž je indikována léčba řadou účinných látek.Polymedikace pochopitelně snižuje adherenci k léčbě, ovšem podávání všech indikovaných skupin léků u takových nemocných je podloženo silnými daty, která dokládají jejich přínos z hlediska prognózy pacienta. Navíc je prokázáno, že kumulace rizikových faktorů dramaticky zvyšuje KV riziko. Při volbě terapie u konkrétního

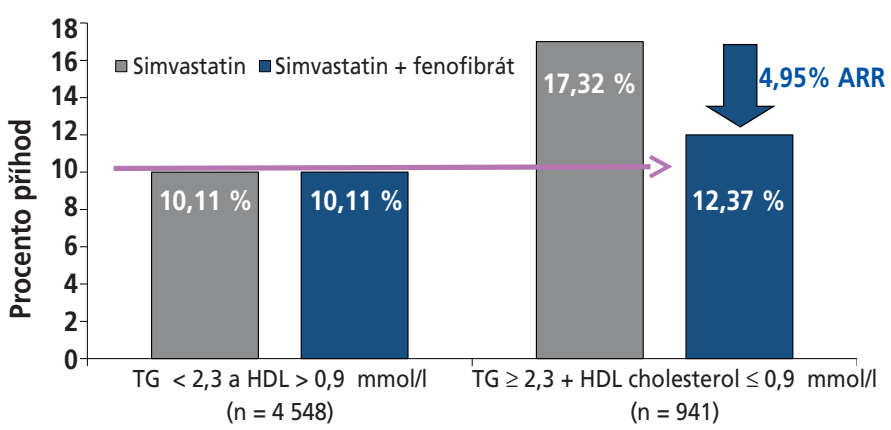

ARR - snížení absolutního rizika

* Hlavní KV přihody definovány jako úmrtí, nefatální IM a nefatální CMP. ACCORD Study Group. New England Journal of Medicine March 14, 2010. Epub.

Obr. 1 - Přidání fenofibrátu $\mathrm{k}$ simvastatinu vedlo ve studii ACCORD ke snížení výskytu KV přihod pouze u pacientů se zvýšenou triglyceridemií a sníženou koncentrací HDL cholesterolu. 


\section{CFEN 0502}

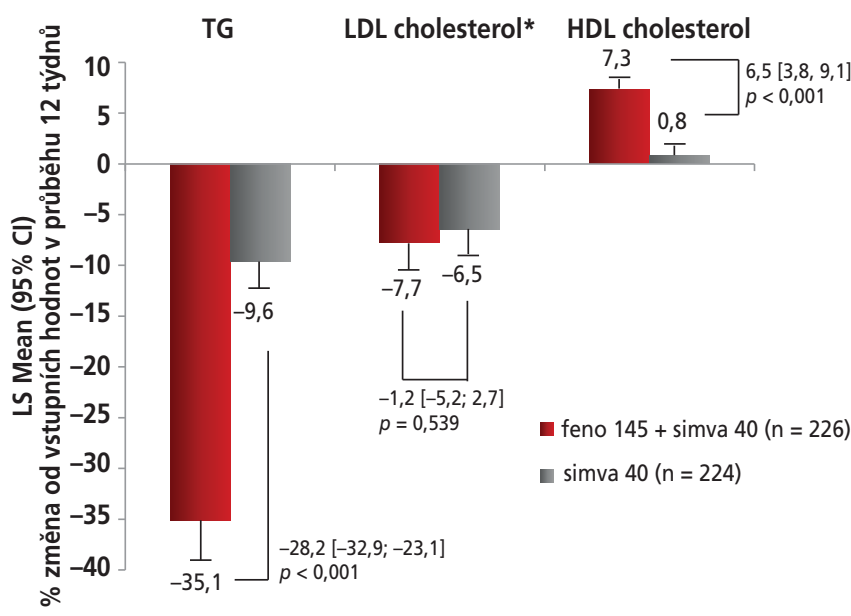

* Zlepšení koncentrací LDL cholesterolu způsobené účinkem kombinační terapie fenofibrát + 40 mg simvastatinu nebylo statisticky odlišné od účinku monoterapie $40 \mathrm{mg}$ simvastatinu.

Cholib Clinical Study Report 100000878

Obr. 2 - Změna koncentrace lipidů po 12 týdnech léčby 40 mg simvastatinu v monoterapii a v nové fixní kombinaci s fenofibrátem $145 \mathrm{mg}$

nemocného je tedy třeba brát na adherenci zřetel a posoudit faktory ovlivňující dodržování léčby ze strany pacienta. Jednou z možností, jak zvýšit adherenci přístupem ze strany lékaře, je používání fixních kombinací. Přestože je léčba dyslipidemie základním pilírem terapie při snižování KV rizika, používání fixních kombinací není na tomto poli tak zavedené jako u hypertenze.

U všech diabetiků 2. typu je primárním cílovým ukazatelem léčby dyslipidemie koncentrace LDL cholesterolu $<2,5 \mathrm{mmol} / \mathrm{l}$. Sekundárním cílovým ukazatelem je koncentrace non-HDL cholesterolu $<3,3 \mathrm{mmol} / \mathrm{l}$ a apo $\mathrm{B}<100 \mathrm{mg} / \mathrm{dl}$. U diabetiků 2. typu s KV nebo renálním onemocněním a u osob nad 40 let s jedním a více KV rizikovými faktory je pro koncentraci LDL cholesterolu doporučena cílová hodnota < 1,8 mmol/l a sekundárním léčebným cílovým ukazatelem je koncentrace non-HDL cholesterolu $<2,6 \mathrm{mmol} / \mathrm{l}$ a pro apo $\mathrm{B}<80 \mathrm{mg} / \mathrm{dl}$.

Základním postupem ve farmakoterapii dyslipidemie je podávání statinů. Metaanalýza 14 studií s 18686 diabetiky potvrdila významný pokles KV rizika při snížení LDL cholesterolu o $1 \mathrm{mmol} / \mathrm{l}$. U diabetiků se ovšem často vyskytuje smíšená dyslipidemie, kdy je cílem léčby především snížení koncentrací TG a HDL cholesterolu. Přínosem pro pacienty s touto aterogenní dyslipidemií je fenofibrát, který ovlivňuje právě tyto dva parametry lipidového metabolismu. Prokázala to nejprve studie FIELD, ve které fenofibrát zajistil významné snížení výskytu KV příhod pouze u diabetiků s nízkou koncentrací HDL cholesterolu a zvýšenou koncentrací TG, a poté studie ACCORD Lipid, ve které přidání fenofibrátu k simavastatinu zajistilo snížení výskytu KV príhod rovněž pouze u pacientů s popsaným lipidovým profilem (obr. 1). Zdá se, že toto pro autory studie možná překvapivé zjištění je velmi snadno využitelné v praxi. Vysvětlením popsaného efektu může být vliv fenofibrátu na výkyvy postprandiální triglyceridemie, která se ukázala jako významný faktor ovlivňující KV riziko.

Všechna tato zjištění vyústila ve vytvoření nové fixní kombinace simvastatinu s fenofibrátem. Pro české lékaře není tato kombinace zcela neznámá, protože 16 českých center se zúčastnilo studie, které hodnotila její účinnost a bezpečnost. Porovnání kombinace fenofibrátu v dávce $145 \mathrm{mg}$ se simvastatinem $40 \mathrm{mg}$ a simvastatinu $40 \mathrm{mg}$ v monoterapii ukázalo srovnatelné snížení LDL cholesterolu v obou skupinách, ale významně větší pokles TG a zvýšení HDL cholesterolu $v$ rameni s kombinovanou léčbou (obr. 2). Tolerance kombinované léčby byla velmi dobrá a srovnatelná s monoterapií každým z prípravků. Volba statinu do této kombinace vychází z existence rozsáhlých dat ve studii ACCORD, která také prokázala dlouhodobou bezpečnost kombinace simvastatinu s fenofibrátem.

Doc. Vrablík upozornil na zvýšení hodnoty sérového kreatininu při léčbě fenofibrátem (o $\geq 20 \%)$, které ovšem není provázeno poklesem glomerulární filtrace, a je proto s největší pravděpodobností dáno mimorenálními mechanismy. Po přerušení léčby se hodnota kreatininu během 6-8 týdnů zcela upraví bez reziduálního účinku na funkce ledvin.

Fenofibrát $v$ nanoformě znamená další zmenšení jeho mikročástic na nanočástice. To vede ke zlepšení biologické dostupnosti, která umožňuje snížení dávky na 145 mg při zachování účinnosti, a navíc k nezávislosti podávání na príjmu potravy a denní době. $V$ praxi se bude fixní kombinace simvastatinu $s$ fenofibrátem podávat $v$ jedné tabletě jednou denně. $K$ dispozici budou dvě síly: 145 mg fenofibrátu/20 mg simvastatinu a 145 mg fenofibrátu/ 40 mg simvastatinu.

\section{Shrnutí}

Jak uzavřel doc. Vrablík, pravděpodobnost dobré adherence může zvýšit použití fixních kombinací. U diabetika s KV rizikem, který užívá osm účinných látek (kyselinu acetylsalicylovou, ACEl, diuretikum. BKK, statin, fibrát, beta-blokátor a metformin), je možné snížit počet tablet užívaných denně na čtyři (ASA + beta-blokátor, ACEI + diuretikum + BKK, metformin a nově statin + fibrát). Při racionalizaci farmakoterapie s využitím fixních kombinací bude od konce roku 2014 možné podávat první fixní kombinaci statinu s fibrátem, obsahující 20/40 mg simvastatinu a 145 mg fenofibrátu v nanoformě.

Pripravila MUDr. Zuzana Zafarová 